\begin{tabular}{|c|c|c|c|c|c|c|}
\hline \multirow{4}{*}{ Impact Factor: } & ISRA (India) & $=3.117$ & SIS (USA) & $=0.912$ & ICV (Poland) & $=6.630$ \\
\hline & ISI (Dubai, UAE & $=0.829$ & РИНЦ (Russia & $=0.156$ & PIF (India) & $=1.940$ \\
\hline & GIF (Australia) & $=0.564$ & ESJI (KZ) & $=8.716$ & IBI (India) & $=4.260$ \\
\hline & JIF & $=1.500$ & SJIF (Morocco & $=5.667$ & OAJI (USA) & $=0.350$ \\
\hline
\end{tabular}

\section{SOI: $1.1 /$ TAS $\quad$ DOI: $10.15863 /$ TAS \\ International Scientific Journal Theoretical \& Applied Science}

p-ISSN: 2308-4944 (print) e-ISSN: 2409-0085 (online)

Year: 2019 Issue: 08 Volume: 76

Published: $08.08 .2019 \quad$ http://T-Science.org
QR - Issue

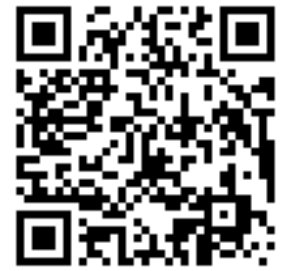

QR - Article

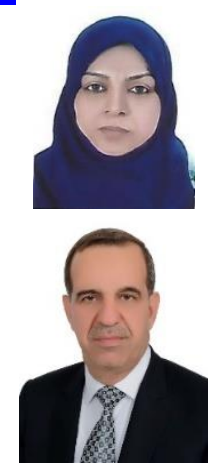

Raghad Abd Abu-Jassim

University of Kufa,

Asst. Lect., Faculty of Arts, Department of the Arabic Language, Al-Najaf, Iraq aliabojassim@gmail.com

Aqeel A. Mubdir Al-kheigani

University of Kufa,

Prof. Dr., Faculty of Arts, Department of the Arabic Language, Al-Najaf, Iraq

\title{
A PRAGMATIC STUDY OF ARGUMENTATION IN THE HOLY VERSES OF THE UNSEEN: LINGUISTIC MECHANISMS AS A REPRESENTING MODEL
}

Abstract: Language employment comes in various forms in response to variant requirements that are specified in their contexts. Such linguistic specifications are seen in the choices that are made by the message sender in the locution in which s/he adopts an adequate strategy to show her/his intention and actualize what s/he aims at. The strategy of persuasion is one of the most prominent interactional strategies that has received its linguistic fame from its discoursal purposes. In order to achieve persuasion in any discourse, speakers might utilize certain linguistic mechanisms to realize discoursal persuasion, which is diverse and complex, stemming from the plethora of human behavior.

Key words: Argumentation, Quran, holy Verses of the Unseen and Arabic language.

Language: English

Citation: Abu-Jassim, R. A., \& Al-kheigani, A. A. M. (2019). A Pragmatic Study of Argumentation in the Holy Verses of the Unseen: Linguistic Mechanisms as a Representing Model. ISJ Theoretical \& Applied Science, 08 (76), 44-52.

Soi: http://s-o-i.org/1.1/TAS-08-76-7 Doi: crossef https://dx.doi.org/10.15863/TAS.2019.08.76.7

Classifiers: Linguistic.

\section{Introduction}

Argumentation might be the most important mechanism to realize persuasive ends. It is regarded as one of the most effective means to actualize persuasion, especially in the area of supporting the idea of believing in metaphysical things far from the perception of the human senses, as argumentation "is not bound to the circumstantial discoursal utilizations rather it is generally inherent in every discourse"(1). That is why; investigating argumentation becomes one of the major developments in the linguistic investigational trends. In addition to the functions of reporting and communicating, language assumes the argumentative function. Therefore, argumentation is considered as a fundamental pillar in building up aimoriented texts, particularly, the discourses and texts that are based on debate and argument. Hence, argumentation assumes a significant place within the realm of pragmatic studies that are based on the basic objectives to invest possible and on hand mechanisms to deliver a specific linguistic message and familiarize the addressee with that message to make him/her on the move towards its achievement"(2). Argumentation exploits certain techniques and mechanisms that affect the conversational recipient to acknowledge the desired ideas and arguments. Therefore, argumentation is indispensable in any discourse especially on communicative levels. In this regard, 


\begin{tabular}{|c|c|c|c|c|c|c|}
\hline \multirow{4}{*}{ Impact Factor: } & ISRA (India) & $=3.117$ & SIS (USA) & $=0.912$ & ICV (Poland) & $=6.630$ \\
\hline & ISI (Dubai, UAI & $=0.829$ & РИНЦ (Russia & $=0.156$ & PIF (India) & $=1.940$ \\
\hline & GIF (Australia) & $=0.564$ & ESJI (KZ) & $=8.716$ & IBI (India) & $=4.260$ \\
\hline & JIF & $=1.500$ & SJIF (Morocce & $=5.667$ & OAJI (USA) & $=0.350$ \\
\hline
\end{tabular}

argumentation is seen as a pragmatic interactional process in which the interactants exchange linguistic and paralinguistic messages that require certain contextual and sociological dimensions of argumentation such as avoiding offensive and violent forms of argumentation except in the presence of disagreement. But this forces the interactional parties to address misunderstanding through debate and rhetorical argument without resorting to violent arguments. It is the socialized rich nature of argumentation that urges the argumentation interacting parties to come up with deductive linguistic means of persuasion through involving other parties (3).

\section{Linguistic Argumentation}

The theory of argumentation in language is attributed to two prominent scholars, namely, Oswald Ducrot and John Claude Anscombre, who have investigated argumentation linguistically and based their work on pragmatic studies, that have paved the way to the emergence of the theory of speech acts by Austin and Searle who proposed adding two speech acts: (the speech act of requiring) and (the speech act of argumentation). As for the pronunciation study of Benveniste and the Bakhtine dialogue, the pragmatic oriented work of which has approached argumentation from a different angle"(4) Those two scholars have established in 1973 a linguistic theory that is concerned with all the linguistic means and the natural language possibilities available to the speaker, echoing the common idea that (we generally speak to influence others)... "This theory is intended to stress the idea that language carries an intrinsic function that is of argumentation"(5). So according to them, argumentation is inherent in language structure itself rather than the discoursal content or the quasi-logical, formal or mathematical structures, as in the case of Perlman and Tyteca (6), who have distinguished between the meanings of argumentation: the standard meaning and the artistic meaning. On one hand, the standard meaning of argumentation is concerned with presenting arguments and passing them with the aim of influencing addressees to produce more effective discourse; this meaning is a distinguishing but insufficient measure of argumentation. Therefore, the nature of the addressees must be taken into consideration, to address them with suitable interactions. Also, the effectiveness of the argumentative techniques utilized in persuasion should be considered, as well as the exploitation of the psychological side of the interacting receivers in order to exercise the required effect on those receivers. On the other hand, the artistic meaning refers to a specific class of relations that are deposited in the discourse in general and listed in interactive speech, and these relationships stand out as scaled measure (Scalaire), which can be measured in degrees (7). Benveniste and the Bakhtines' linguistic efforts create a distinct pragmatic tendency in rejecting the idea of separating semantics (sentence meaning) from pragmatics (utterance meaning) in terms of the context of their research that is the integral part of the Pragmatique Integree(8). In this regard, Language actualizes a speech act rather than demonstrates a description of external reality. As for the statement and its contextuality, it is analyzed in accordance with the link between the linguistic data belonging to the linguistic component, the non-linguistic component that is close to the meaning of the words, and the rhetorical component that actually defines the meaning of the statement (contextual actualization) (9).

\section{Linguistic Means:}

The language of argumentation is a means of imposing linguistic authority on others by persuading them to consent to the desired argument (10). Therefore, the addresser utilizes linguistic units that conform to his/her speech, uses them and employs them to exploit their various argumentative capabilities and their different characteristics that vary according to their contexts in a way which realizes the major aim of the discourse, making the discourse linguistically richer and supporting the relationship between the arguments and their ends. They are a set of driven linguistic tools and means, which are employed by the sender in his speech to present his arguments in linguistic forms that comply with their context and represent the rules governing the argumentative relations between arguments and results to serve the purposes of persuasion. These tools or forms include:

\section{A - Causation Expressions:}

Causation Expressions is a set of linguistic tools that are utilized by the producer of the discourse of argumentation to build their arguments and their structures, since employing them in speech as a justification of a verbal or a supposed question by the addressee (11), including:

The Causation Lam لام(that):

Perhaps it is the most employed linguistic tool that is used in Arabic argumentation. Its argumentative power lies in causative explanations of acts, whether it is not explanation or Lam of the accusative Kay (that in order that) (12), which has been mentioned in several Quranic verses, including the verse:

"O you who believe, God will surely try you with the game that you take with your hands or your lances, in order to know who fear Him unseen. Whosoever transgresses after this will suffer grievous punishment." (13)

This is one of the verses of Quranic rulings, which comes in the context of the prohibition of hunting in the course of the holy event of Ihraam. (The use of Liyablowakom يبلبوكم (to try you) which is a conditional answer to a Holy Swear condition (By 


\begin{tabular}{llllll} 
& ISRA (India) $=3.117$ & SIS (USA) $=\mathbf{0 . 9 1 2}$ & ICV (Poland) & $=\mathbf{6 . 6 3 0}$ \\
Impact Factor: & ISI (Dubai, UAE) $=\mathbf{0 . 8 2 9}$ & PUHЦ (Russia) $=\mathbf{0 . 1 5 6}$ & PIF (India) & $=\mathbf{1 . 9 4 0}$ \\
& GIF (Australia) $=\mathbf{0 . 5 6 4}$ & ESJI (KZ) & $\mathbf{8 . 7 1 6}$ & IBI (India) & $=\mathbf{4 . 2 6 0}$ \\
& JIF & $\mathbf{1 . 5 0 0}$ & SJIF (Morocco) $=\mathbf{5 . 6 6 7}$ & OAJI (USA) & $\mathbf{0 . 3 5 0}$ \\
\hline
\end{tabular}

Allah to teach you through testing in order to test your obedience capacity); Then comes the Arabic indefinite term "sha'y i.e. a thing شيء" to conclude that this is not a big deal or a grand test just like the burdening rules of killing oneself or abandoning privileges. Allah has tested the people of Prophet Muhammad by the test of hunting while performing Ihraam, as He the Almighty has tested the children of Israel with Sea fishing on Sabbath. In addition to the warning that those who did not stand such little test, "Will they endure greater burdens?" The Causation Lam (that) is combined with the present tense to show the cause of this fall in saying: (to teach those who disobey by the unseen), in this verse, there are two major points: The first point, it metaphorically describes Allah here because Allah is All-knowing and cannot be subjected to the limits of time and place, therefore, the Verse meaning is changed accordingly; The second point is in the verse (In the unseen) There are two dimensions, the first one is about those who fear Allah because they believe in the unseen, while the second dimension is concerned with their sincere belief and dedication so they fear Him for His All presence or metaphoric absence(14). As for the use of the Prepositional (Ba/ by) in the Accusative case, it refers to the meaning which says that they fear the unseen for the unseen. Thus, the reason behind the employment of the Causation Lam (that) is to warn them "Those who disobey shall expect consequences." i.e., the punishment of Allah will fall on the aggressor. Moreover, this little test or thing regarding (the prohibition of hunting in the course of the holy event of Ihraam) even when the hunts approach them in their tents, they are not permitted to hunt while being under Ihraam. This is only to stress the fact that it is a test for them to tell who is going to be delivered and who is going to be punished whether being in the very act or in private; accordingly their punishment is justified for disobeyed Allah's prohibiting commands. This can be represented by the following figure:

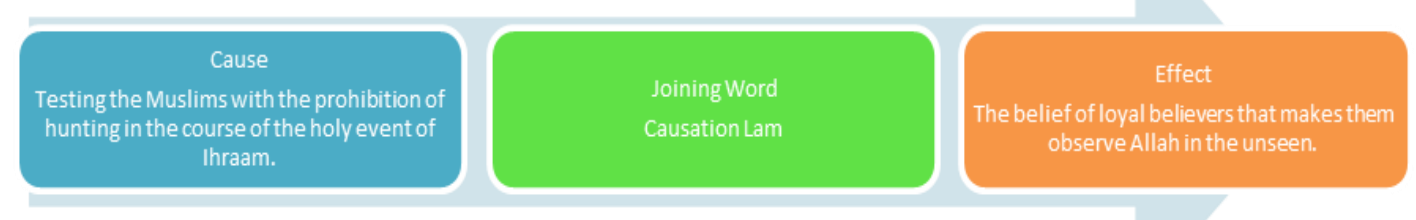

"We have surely sent apostles with clear signs, and sent with them the Book and the Scale, so that men may stand by justice; and We sent down iron which causes much distress but also has advantages for men, so that God may know who helps Him and His apostles in secret. Verily God is All-powerful and Allmighty."(15)

In this verse the Holy book refers to the theoretical symbol of power (the Scale) and the practical symbol of force (the iron) to assure steadiness in the face of hazards. This verse has a linguistic order that is based on referential meaning, which echoes the logical organization of human beings interests. So, taking care of the spiritual side of man comes on top of the necessities, and then nurturing the interests of the body and restraining from unwanted acts are metaphorically represented in this verse. This order tries to establish the fact that engaging with Allah, the Creator, as well as His creation including our loved ones requires treating them with equality and justice, consequently the verse referred to the scale, while mentioning iron stresses the way in which we deal with foes. In light of the verse, Man is regarded either as the source openness and easy communication, who enjoys nothing but spending time with the Holy Book, as the most inquiring and reasonable person who must resort to the scale of evidence and argument, or seen as a stubborn and man of pertinacious arguments who must be rejected with the force of iron.

Moreover, another interpretation is attributed to religion fundamentals and/or branches, in the either sense of knowledge or deeds, the fundamentals are enforced in the book, while the branches are the actions and deeds which are measured by means of the scale of justice and interest, which is a symbol of the observance of justice, whereas iron is to discipline those who have breached one of the two routes. Additionally, Allah specifies the provisions of justice and equity as well as the scale in the Quran to urge people to follow and enforce those judgments based on justice and equity which are the major concern of the kings. However, iron force is required to balance the disobedient actions. This interpretation proves the significant rank given to clerics of the book over that of Kings Keepers of Quranic laws enforcement. As for apparent divine aid for hypocrites or those who seek earthly benefits of life, this merciful aid is nothing as compared to the merits and glorious positions that are granted to those who truly believe in the heavenly unseen. Then, Allah the Almighty overstresses His overwhelming power over creatures to reveal those who will faithfully come to the aid of Godly commands and His messengers under different circumstances including the unseen; still the Almighty does not need that aid or support since He is All- 


\begin{tabular}{llllll} 
& ISRA (India) $=3.117$ & SIS (USA) $=\mathbf{0 . 9 1 2}$ & ICV (Poland) & $=\mathbf{6 . 6 3 0}$ \\
Impact Factor: & ISI (Dubai, UAE) $=\mathbf{0 . 8 2 9}$ & PUHЦ (Russia) $=\mathbf{0 . 1 5 6}$ & PIF (India) & $=\mathbf{1 . 9 4 0}$ \\
& GIF (Australia) $=\mathbf{0 . 5 6 4}$ & ESJI (KZ) & $\mathbf{8 . 7 1 6}$ & IBI (India) & $=\mathbf{4 . 2 6 0}$ \\
& JIF & $=\mathbf{1 . 5 0 0}$ & SJIF (Morocco) $=\mathbf{5 . 6 6 7}$ & OAJI (USA) & $\mathbf{0 . 3 5 0}$ \\
\hline
\end{tabular}

powerful (16). So, The Causation Lam (that) is utilized here to state the reasons behind sending them the Book and the Scale, so that men may stand by justice; sending down iron only to test the people and show them part of the unseen and Godly overwhelming knowledge of the peoples' conscience and every single deed of the people whether these deeds are done faithfully or for hypocrite purposes.

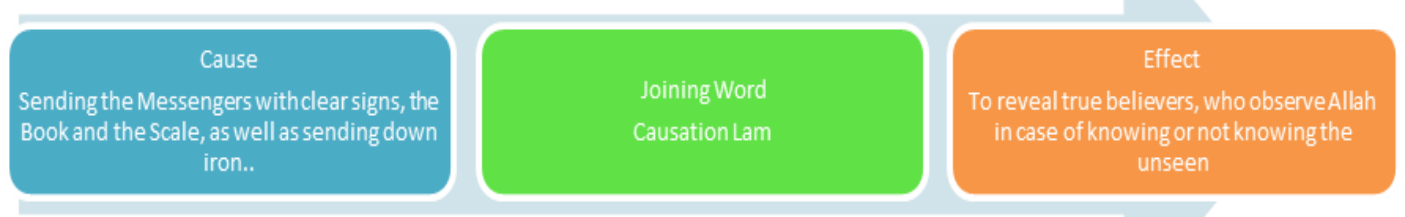

The causative object, and the accusative (Kay كي), which transforms the form of the present verb into the accusative case are amongst the linguistic tools of causality; but they are not employed in the verses of the unseen.

\section{B - Description:}

Description comprises a number of linguistic tools that are utilized to achieve persuasion in the interest of argument presenter, it is one of the most effective linguistic tools in argumentation, and includes: the Active Participle, Passive Participle. Description is one of the argumentative means that is utilized by the sender of the argumentative message to persuade the receiver of the message (17) and counter their counterclaims. Consequently, the use of titles derived from adjectives is an indication of the degree of argumentation that belongs to a graded linguistic measure of choices from which the argument presenter would choose the exact arguments to argue with (18), as stated in following verse:

Say: "O you Jews, if you claim that you are the favourites of God apart from all men, then wish for death, if you speak the truth. But they will never wish for death because of what they had done in the past, and God knows the sinners well. Tell them: "Death, from which you run, will surely come to you. You will then be sent back to Him who knows the unknown and the known, who will tell you what you used to do". (19)

Here the Quran points out the Jews' denial of the Prophet's message and his unquestionable features that are mentioned in the Torah and their other religious books "We have witnessed -for the first time in the Qur'an that was revealed to the Prophet (Peace and Blessings of Allah Be Upon Him) in Medina- the employment of the expressions "Jews and Torah" on the one hand and the use of the expressions "Christians and Gospel" on the other hand, a prominent appearance in terms of frequency that has accompanied the Quran arguments has involved both Jews and Christians and criticized them at the same time"(20).
Scholars have disputed over the derivation of the Arabic term 'Haddoo هادو'. It is said they are called so because they repented after worshiping The calf due to their saying in Surat Al-A'raaf verse (156): (إنـا هدنا إليك We have repented to Thee)), i.e., repentance And they said that the heavens and the earth moved when God revealed the Torah to Moses (Peace Be upon Him) at Sinai Mountain (21). Another interpretation states that they are attributed to Judas, the eldest son of Jacob according to The Torah. Say: O Muhammad, to those who are called Jews: if you claim that you are the supporters of Allah, and that Allah will help no human but you, so do you wish for death, and you do not wish death as you know the sincerity of the Prophet (Peace and Blessings of Allah Be upon Him). The death that you escape cannot be escaped and then you will return to the Lord of worlds of the unseen and the testimony, and we shall inform you about your what you have done in your past life deeds)), whether you flee from death and care for it or not, then it is your end and your refuge, and you benefit not from your escape. The employment of the Arabic term 'Haddoo هـادو' is used only in places where the addresser wants to blame the Jews and remind them of their sins and repentance, which are utilized here as an argument to convince the addressee of the idea that people with such fluctuating nature as the "Bani Israel / sons of Israel", which means "the Chosen Ones", this expression indicates Selection, Preference, and Blessing on them even if they are lined up as they claim, they must be addressed directly with this expression but the Qur'an has defied their claim and refuted their argument by a stronger argument utilizing the verb "taamaloon تعملون/ have done" rather than the term "Tafaaloon تفعلون / تعلون have acted' since ce" deed" belongs with the situation,

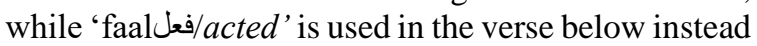
of 'did عمل'

"HAVE YOU NOT seen how your Lord acted upon the people of the elephants? (22) And the verse "Have you not seen what your Lord acted upon the 'Aad". (23) 


\begin{tabular}{|c|c|c|c|c|c|c|}
\hline \multirow{4}{*}{ Impact Factor: } & ISRA (India) & $=3.117$ & SIS (USA) & $=0.912$ & ICV (Poland) & $=6.630$ \\
\hline & ISI (Dubai, UAI & $=0.829$ & РИНЦ (Russia & $=0.156$ & PIF (India) & $=1.940$ \\
\hline & GIF (Australia) & $=0.564$ & ESJI (KZ) & $=8.716$ & IBI (India) & $=4.260$ \\
\hline & JIF & $=1.500$ & SJIF (Morocce & $=5.667$ & OAJI (USA) & $=0.350$ \\
\hline
\end{tabular}

All these annihilations have occurred quickly and not slowly ... The matter with (faalde / acted) is that it does not require a stretch of time, but the act is done once and quickly "(24), since Allah has a preknowledge of all creatures deeds at various times; consequently, the utterance "Lord of the world of the unseen and the seen...." is used to stress the idea that Allah is All-knowing and reveals the fact about the message of the Prophet whether you (Jews) confess or not.

The Active Participle:

It is a derived noun that indicates the event, occurrence and agent's act. It is "A noun that is derived from the act of the agents who have realized and produced an action in the sense of occurrence, and the grammatical form of which is morphologically derived from tri-letter-base-form verb or other verbal forms in the present tense with diacritic Dhama over the $M$ initial letter of the verb and Kasra diacritic on the pre-ending letter"(25) Ibn Malik (died in 672 A.H.) limited meaning of the active participle by saying: "It is the distinguishing feature of the actor with feminine and masculine forms in the present meaning or meaning of the past forms"(26). The active participle is one of the descriptive models used by the sender of the argument in his speech, the sender may employ direct description, or they might do so with certain conversational discourses (27) as in the verse:

So, go to your father and tell him: 'O father, your son has committed a theft. We bear witness to only what we know; we could not prevent the unknown. 82. Enquire from the people of that city, or ask the men of the caravan with whom we have come. We are verily speaking the truth."" 83. "No," said (the father). "You have made up the story; but patience is best; God may bring them back to me. He is All-knowing and Allwise."(28)

In this verse, the sons of Jacob utilize (your son / (ابنك )to offer their argument in "O father, your son has stolen." and do not use (our brother أخانا )when they ask their father to send Benjamin with them in "They said, ' $\mathrm{O}$ father, here is our merchandize traded not; still we shall cater for our family and keep our brother ...) ((Yusuf / 65). This might be taken as an introductory argument to the yet-to-come arguments they are going to deliver, therefore they employ (your son) rather than (our brother) because they intend to consolidate showing their contempt for the alleged theft issue and disavow from their past pledges of keeping their brother by means of using the confirming Arabic nominal sentence; and then present their arguments; because they were accused of killing Joseph (Peace Be upon Him). Thus, the first argument is exaggerated: (We do testify but what we have seen), to show that they were not definitely aware of this matter; since the measure was retrieved from Benjamin's riding camel. Likewise, they justified telling the king's men that the thief is to be punished with enslaving in the law of the
Israelites, they did not know that Benjamin would be accused of theft. Moreover, they could not tell that Benjamin has robbed or not, however, the king's the measure has been found on him, so apparently he was the thief. They only said that when Jacob replied reprimanding them: "how did the king's men know that the thief is to be enslaved for stealing?" (29) Then they have presented Jacob with the second argument "We know not the unseen". This argument comprises several manifestations; the first is that they have witnessed the retrieval of the measure from Benjamin's riding camel. No one knows what really happened but God. While the second manifestation according to E'krema (a cleric) implies the sense that someone concealed it in his ride in the night due to the fact that (AlGhaib الغيب/the unseen) is used to denote the night in some Arabic dialects. And the third one according to Mujahid, al-Hasan and Qatadah is that: "We did not know that your son would steal, if we had known that he would do that, we haven't gone to the king and pledged to protect him. As for the fourth meaning, which is related to Jacob's (Peace Be upon Him) reproaching them by saying: "Suppose he had stolen; yet how did the king know that the Sons of Israel had prescribed that whoever steals is to be enslaved? It was you who told the king about this verdict for an unspoken purpose" The sons replied: "We have mentioned this sentence prior to the theft incident. We did not pre-know that this incident would happen and this is shown in the verse "We know not the unseen". in reference to this meaning (30), since they are under accusation so they have utilized the active participle (Hafideen_حافظي/keepers) because it is linguistically more stable and confirming than the verb keep) For the importance of rejecting the charge. Accordingly, the active participle is not exploited for mere description rather it is used for argumentative purposes to influence the recipient and convince him, due to the argumentative context in which they are placed to argue for revealing their innocence that their father doubts. The active participle is employed both an argument and counter- argument as in the verse:

They say: "How is it that no sign was sent by his Lord (to His Prophet)?" Tell them: "Unknown things are only known to God. So watch and wait (for the sign); I am waiting and expecting with you.20"(31)

This verse presents the suspicions the people offered in their denial of the prophecy of the Prophet (Peace Be upon Him and His Progeny); they have said: "This Quran encompasses only words, and a book with words only is not miraculous; neither Torah is the miracle of Moses (Peace Be upon Him) nor the Gospel is the miracle of Jesus (Peace Be upon Him) as these two prophets have demonstrated various miraculous acts that have confirmed their prophecies. So, the Prophet's people have asked him to bring about another miracle besides the Quran as a proof of the Prophet's prophecy; therefore, Allah commands the Prophet (Peace Be upon Him and His Progeny) to 


\begin{tabular}{|c|c|c|c|c|c|c|}
\hline \multirow{4}{*}{ Impact Factor: } & ISRA (India) & $=3.117$ & SIS (USA) & $=0.912$ & ICV (Poland) & $=6.630$ \\
\hline & ISI (Dubai, UAI & $=0.829$ & РИНЦ (Russia & $=0.156$ & PIF (India) & $=1.940$ \\
\hline & GIF (Australia) & $=0.564$ & ESJI (KZ) & $=8.716$ & IBI (India) & $=4.260$ \\
\hline & JIF & $=1.500$ & SJIF (Morocce & $=5.667$ & OAJI (USA) & $=0.350$ \\
\hline
\end{tabular}

respond saying: "Say, the unseen is in God's knowledge so wait for it, I am waiting just like you." The Messenger has presented them with the argument that he is waiting for it with them, They knew that he did not read books or no teacher taught him for the past forty years, and was not engaged in thought and learning, then this divinely elevated book is revealed by the person who shows no signs of high educational standards prior to the divine revelation of the message as a compelling proof that it is a miracle. And any request or suggestions for additional miracles are not required to prove his prophecy, as they are limited to the will of God if He wishes to reveal it or not, all that is part of the unseen (32).

Moreover, He uses the letter of excitation (Laula $\gamma_{g} \_$/if), for narrowing the request as the passive structure is employed, and perhaps the passive is utilized here to draw attention to the proof of sending the Messenger of God, and God is the only One Who pre-knows the unseen, reveals what lurks in their minds and proves the truth of the message, urging them to accept the forthcoming arguments, since they have asked for something extraordinary due to their ignorance of the essence of things and their illusions. They assume that God is keen to show the sincerity of the Messenger and is provoked by their weak refutations; therefore He hastens to compete with their denial and if He does not do so He is dumbstruck by their allegations. Nevertheless, neither Allah nor his Messenger are influenced by such suspicions, since Allah's actions are only initiated by wisdom; therefore sending them the Prophet is an act of mercy and divine means that is intended to reform the ethics of their society. The Quranic reply has a threatening sense فقل انما الغبي لله Say, the unseen is in God's knowledge 2, the deduction Fa' فـ is combined with the verb ( ( (Say/ Qul counter their claim with a confident counter argument followed by Lam that indicates the right of property to confirm the fact that only God is All-knowing in terms of the unseen. Answering what they have proposed with the idea of the limited answering authority of the messenger in this regard, to inform them that they boldly question the power of Allah the Almighty (33), consequently, the verbal sentence (I am waiting for it with you) is a deduction about the phrase (but the unseen). So both of you have nothing but to wait and see for themselves Allah's actions, from Whom they (people of the prophet) expect nothing but evil, and the accompaniment in (with you) is used to involve them in the absolute comprehensive waiting. While the active participle (Montadharin منتظرين /waiting) is used to indicate the firmness of the messenger position in his waiting along with them and that he speaks not but the commands of Allah in his responses to them, as well as to show a kind of solidarity in order to influence their thinking by assuring them he is one of them and is concerned with their interests. Additionally, he seeks nothing but their good and this threat is in their own interest. It is clear that the utilization of the active participle is more persuasive and influential for the addressee; i.e. here the semantic signification is combined with the linguistic form to realize the intended meaning, its purpose is to guide the recipient towards complying with the conversational argument and surrendering to it effect.

The Passive Participle:

What has been stated about the Active Participle can be applied to the Passive Participle excepting that it is followed by Pro-agent or subject of the passive (34), it is "a derived adjective that has received the act/effect of the actor or agent " (35), only "the grammatical form of which is morphologically derived from tri-letter-base-form verb in the form (mafu'low and from other verbal forms with diacritic Dhama over the $\mathrm{M}$ initial letter of the verb and Fatha diacritic on the pre-ending letter"(36). Exploiting the addressee linguistic forms (the passive) in the construction of argumentation in response to the demands of the recipients and persuading them, especially in the Holy Quran is pursued to avoid violence in the Quranic discourse, the addressee uses different persuasive devices to influence the recipients and change their beliefs. In terms of argumentation, argumentative interactions might be employed to freeze the conversational and intellectual abilities of the addressees that are employed in coming back with counter responses. Thus, fallacious arguments are delivered to listeners to make them accept the uttered fallacious messages; consequently, the listeners are required to interpret and decompose the uttered messages and the objectives behind them to defeat their opponent maneuvers by refuting their erroneous arguments, as in the Quranic verse below:

"Or do you demand any wages from them so that they are burdened with expense? (40). Or do they have knowledge of the Unknown which they write down? (41)."

In these verses, Allah the Almighty moves to another invalidation of their excuses in their reluctance to respond to the message of the Prophet starting from verses (36) to (41) in : (How do you judge or whether you have a holy book), (or have you any faith), (or have they any partners). Allah addresses here the infidels in a rebuking tone in "If you ask them a reward for delivering the message" which is coupled with "Have you a holy book in which you study". In the above mentioned verses, Allah has mentioned all the fallacious arguments that would be raised against the Message, which is why He says: (do you demand any wages from them so that they are burdened with expense) if you demand any wage they would feel like being in debt that burdens them without any fair favour you have delivered; therefore, the verse insists on the need for a non-rewarding and non-punishing dimensions of the Prophet's call, which are necessary, (or they know the unseen from which they write). This means that they are not certain 


\begin{tabular}{|c|c|c|c|c|c|c|}
\hline \multirow{4}{*}{ Impact Factor: } & ISRA (India) & $=3.117$ & SIS (USA) & $=0.912$ & ICV (Poland) & $=6.630$ \\
\hline & ISI (Dubai, UAI & $=0.829$ & РИНЦ (Russia & $=0.156$ & PIF (India) & $=1.940$ \\
\hline & GIF (Australia) & $=0.564$ & ESJI (KZ) & $=8.716$ & IBI (India) & $=4.260$ \\
\hline & JIF & $=1.500$ & SJIF (Morocce & $=5.667$ & OAJI (USA) & $=0.350$ \\
\hline
\end{tabular}

of the validation of the claims and arguments they raise against the message, and they record and inherit these claims and should support them with evidence. Here, the Quran's denying the idea that they have an established argument that supports their claims of living under the best circumstances, or having dates and charters that prove these claims, or great supporters. The direction of interaction asserts the fact that they would not be harmed by answering the call of Islam. This argument tries to refute the probable excuses on the assumption that the Prophet has asked them to compensate him for the deliverance of their minds and souls by his call; however they would respond to this call due the heavy burdens of the wages required by the Prophet. Moreover, the employment of the interrogative with a rhetorical force to reject the assumptions that lurk in their hearts, presumably necessitated by the extrapolation of their intentions based on their interest in calling for good and guidance. Likewise, the Causation Lam لام is used to stress the fact that they assume that you will burden them with your call so their arguments are raised to refuse your call. Thus, the passive participle precedes the agent here to refer to the hardship effect which is combined with interval that introduces this hardship (38). The above-mentioned counter arguments to counter the claims that might be raised in this regard, then another type of counter argument is triggered, namely the invalidation of a presumed argument they count on to get some unseen information that people do not know, i.e. the information that is in God's knowledge, and is referred to by (the unseen الغيب). Accordingly, the interrogative (Have they the Unseen? (عندهم الغيب) is utilized here to say that they have hidden or unseen knowledge that is supposedly in God's custody. The fronting of the prepositional phrase c to assure their possessing unseen knowledge that in turn asserts this false argument of knowing the unseen ; so the use of the passive participle (مغرمون indebted/burdened ) is intended to consolidate the aforementioned argument, as people normally avoid fatigue or what causes them stress and things that come against their will. In other words, this part of verse accurately portrays how heavy the burden of the call for Islam is in the eyes of those who disbelieve as if it comprises imposing a wage or a debt in return of following this call. This meaning is realized by combining both the semantic signifier and the syntactic form of the passive participle with the purpose of uncovering their false arguments and rejecting them, and then directing the recipient to respond to the Quranic addressing discourse and accepting it.

C- Undisputed Outcomes:

A group of scholars consider some discourses as undisputed extra outcomes since they provide discourses with nothing significant. However, a examination of these ones reveals their argumentative signifying function which is called "representation", meaning multiple definitions or limitations, but the unity of the identifier (39). Multiple limitations are divided into three ones: real, formal, and verbal. The real limitation refers to the essence of things so it is an answer to the question (what is it?)... The formal limitation: is the verbal self-explanatory and necessitating expression that qualifies essential and necessary qualities as in the verse that limits having wine: (a fluid that bubbly foams with acidic taste and is preserved in casks) collecting these qualities produces wine, so that no wine comes out of it. As for the Verbal one: It is explaining words with commoner words (40), as in using drink for (wine), and the "White House" for the U.S.A. Government. Hence, expressions with presentational, descriptive, and /or explanatory linguistic intentions are regarded as argumentative devices that represent diverse definitions of different linguistic layers of one identity, from which the choice is determined by what the sender wishes to convey to the addressee and persuade him/her, as well as his view of things(41). In this regard, the verses of the unseen that comprise undisputed outcomes which are represented by multiplicity of Godly qualities that describe the Lord of the Worlds which are intended to establish a solid undisputed argument to face the false counter claims raised by rejecting arguers; this why multiple definitions are employed in this verse to define a single identifier in order to clarify and describe his qualities, providing the recipient with un rejected argument.

He is God; there is no god but He, the knower of the unknown and the known. He is the benevolent, ever-merciful. 23. He is God; there is no god but $\mathrm{He}$, the King, the Holy, the Preserver, Protector, Guardian, the Strong, the Powerful, Omnipotent. Far too exalted is God for what they associate with Him. 24. He is God, the Creator, the Maker, the Fashioner. His are all the names beautiful. Whatever is in the heavens and the earth sings His praises. He is all-mighty and allwise. (42)

These verses are intended to bring forth the undisputed result of the preceding verses in the same Sura that have referred to the denial of the Sons of AlNadheer بنو النضــير (A Jewish tribe used to live in Medina) the treaty they have signed with the Prophet, as well as their verbal instigating acts that have urged the Hypocrites in Medina to oppose Godly commands and the Messenger's teachings, and finally their great fall in this life and the Hereafter. It is obvious they give no heedfulness to God in their actions and forgot about Him, so they did not choose what was good for them and the prosperity of their life and their future has been lost and demolished. Thus, whoever believes in Allah, His Messenger and the Dooms Day should remember Allah and not forget Him and consider his/her deed, as these deeds are preserved by Allah (43). And these verses come to address all people in different times and places, and ask them to think about 


\begin{tabular}{llllll} 
& ISRA (India) $=3.117$ & SIS (USA) $=\mathbf{0 . 9 1 2}$ & ICV (Poland) & $=\mathbf{6 . 6 3 0}$ \\
Impact Factor: & ISI (Dubai, UAE) $=\mathbf{0 . 8 2 9}$ & PUHЦ (Russia) $=\mathbf{0 . 1 5 6}$ & PIF (India) & $=\mathbf{1 . 9 4 0}$ \\
& GIF (Australia) $=\mathbf{0 . 5 6 4}$ & ESJI (KZ) & $\mathbf{8 . 7 1 6}$ & IBI (India) & $=\mathbf{4 . 2 6 0}$ \\
& JIF & $=\mathbf{1 . 5 0 0}$ & SJIF (Morocco) $=\mathbf{5 . 6 6 7}$ & OAJI (USA) & $\mathbf{0 . 3 5 0}$ \\
\hline
\end{tabular}

what or whom they worship: here the unseen means what is not seen or expected by people, the witnessed refers to what is seen or expected by people, while the holy means flawless creator that is matched to the eulogized by the angels the Lord of Angel and soul. As for the peaceful, it comes in the sense of safety, which is described as an exaggeration in describing his correctness which is far beyond faults as He is the source of safety, the believer and the grantor of security, the dominant over everything, the mighty omnipotent who forced his creation to what he wanted, The pride source and it is said: proud of keeping justice among his worshiping creatures, and the Creator of what is estimated, and the distinguishing of some from the different forms, and the representative, in a sense that $\mathrm{He}$ distinguishes what He sees the difference of forms (44). Although, These verses are dedicated for counting and explicating the holiest and greatest attributes of Allah the Almighty and characterizing the Almighty with the most sublime qualities of Perfection and Holiness that are witnessed in the heavens and the earth.
However, mentioning these attributes reminds those who count Allah's Attributes of perfection and their corresponding attributes of deficiency ... Thus, relating this verse to the previous verse that stresses

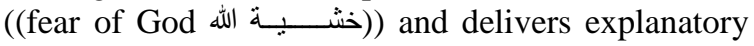
reasoning for the submissiveness of the mountain and its cracking due to the fear of God as if it tries to say these things can only attributed to Him, Because He is God; there is no god but $\mathrm{He}$, the knower of the unknown- to the end of these verses " (45) The Quran employs these limits as different definitions for one Self-existent identifier, and these definitions apply only to This Divinity. He is the God who has no other god, and then the verse proceeds to specify the other qualities that cannot characterize but Allah, and is used in a distinctive way to present the undisputed outcome of argumentation, i.e. defining Allah the Almighty by the effects of His Actions, which are not shared by anyone else and this the most elevated undisputed argument of Allah's Godliness and Divinity. This argument can be represented as follows:

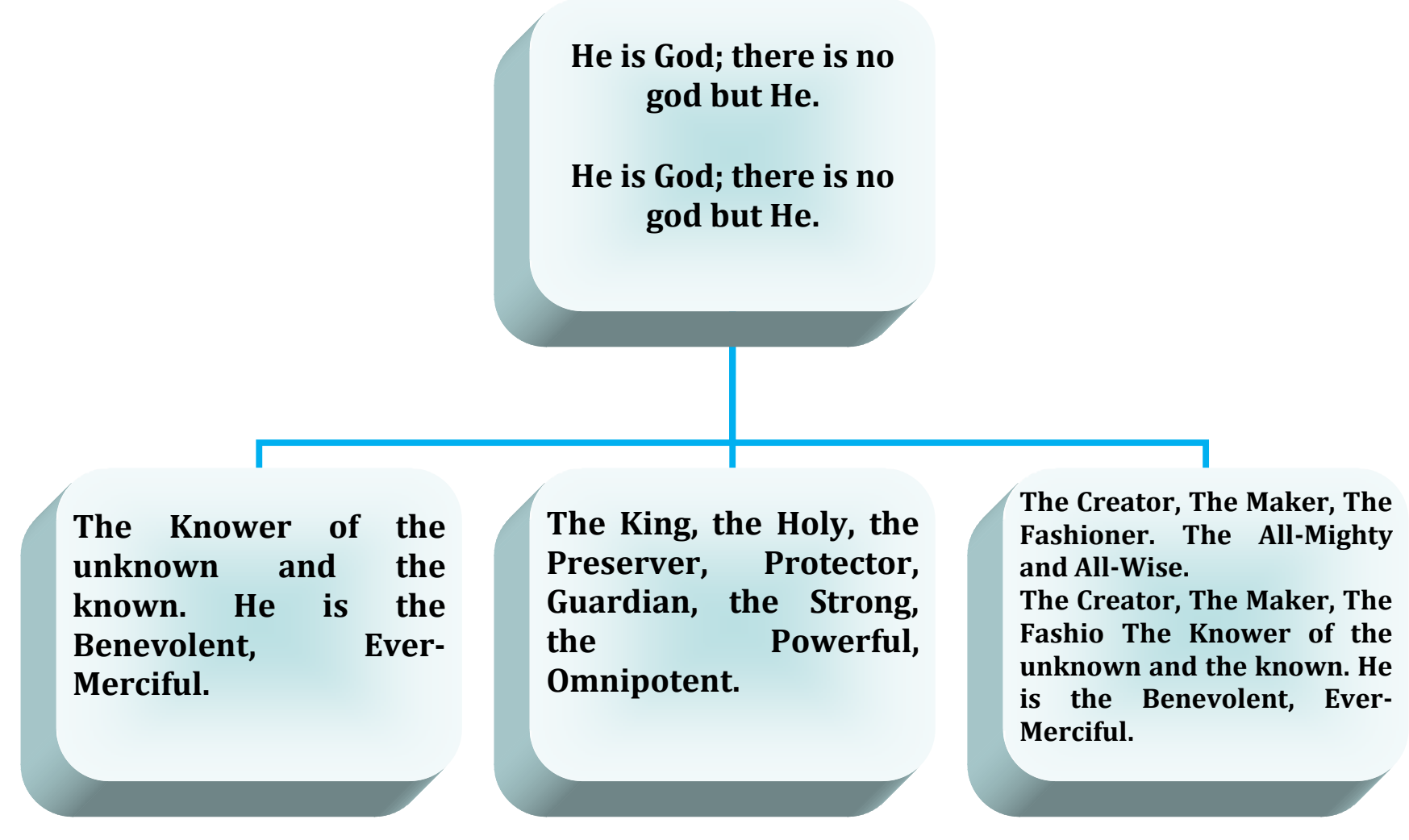

Therefore, the linguistic tools are employed with significant pragmatic employment in argumentation by investing the argumentative power they comprise to achieve the effect on the interactional recipient and convince him/her to change his beliefs and ideas. 


\begin{tabular}{llllll} 
& ISRA (India) $=\mathbf{3 . 1 1 7}$ & SIS (USA) $=\mathbf{0 . 9 1 2}$ & ICV (Poland) & $\mathbf{= 6 . 6 3 0}$ \\
Impact Factor: & ISI (Dubai, UAE) $=\mathbf{0 . 8 2 9}$ & PUHL (Russia) $=\mathbf{0 . 1 5 6}$ & PIF (India) & $=\mathbf{1 . 9 4 0}$ \\
& GIF (Australia) $=\mathbf{0 . 5 6 4}$ & ESJI (KZ) $=\mathbf{8 . 7 1 6}$ & IBI (India) & $\mathbf{4 . 2 6 0}$ \\
& JIF & $\mathbf{1 . 5 0 0}$ & SJIF (Morocco) $=\mathbf{5 . 6 6 7}$ & OAJI (USA) & $\mathbf{0 . 3 5 0}$ \\
\hline
\end{tabular}

\section{References:}

1. (2011). Argumentation and Argumentative Deduction: Elements of a Theoretical Survey, Habib A'rab, Journal of the World of Thought, No. 1, volume 30, National Council for Culture, Arts and Letters, Kuwait, September 2011: 100.

2. (2008). Argumentation in contemporary rhetoric: a study of the eloquence of contemporary criticism, d. Mohammed Salem Al-Amin Al-Taleb, 1, New United Book House, Beirut, Lebanon.

3. (n.d.). the Argumentative analysis of the Quranic discourse models and observations, d. Zakaria al-Sarti, a paper in a book: the analysis of the Argumentation of the discourse, supervision and presentation: Dr. Ahmed Kadem, and Dr. Saeed Al - Awadi.

4. (n.d.). Eloquence of Persuasion in Debate, Dr. Abdul Latif Adel: 95.

5. (n.d.). Language and Argumentation Dr., d. AbuBakr al-Azzawi: 14.

6. (n.d.). Argumentation in the Quran, Dr. Abdullah Solah: 33 .

7. (n.d.). Pragmatics and Argumentation Entries and Texts, Saber al-Habashah: 21.

8. (n.d.). The Theory of Argumentation in Language, Dr. Shokri al - Mabkhout, A paper in book: The Most Important Theories of Argumentation in the Western Traditions of Aristotle up To Current Days: 363.

9. (n.d.). ibid., 356.

10. (n.d.). Argumentation: Its Concept and Fields, Dr. Hafiz Ismail Alawi: 2/33.

11. (n.d.). Argumentation: Its Concept and Fields, Dr. Hafez Ismail Alawi.

12. (n.d.). Speech Strategies, Abdulhadi Al - Shihri: 479.

13. (n.d.). Surah Al - Maida (94).

14. (n.d.). Mafteeh Al-Ghaib/ The Keys to the Unseen, Al - Razi.

15. (n.d.). Surat Al-Hadid.

16. (n.d.). Mafteeh Al-Ghaib/ The Keys to the Unseen, Al - Razi :15/243.

17. (n.d.). Speech Strategies, Abdul Hadi Al Shihri: 486.

18. (n.d.). Speech Strategies, Abdul Hadi Al Shihri: 487.

19. (n.d.). Surat Al-Jumu'ah (6/8).
20. (n.d.). Argumentation in the Quran, Abdullah Salah: 221.

21. (n.d.). Rhetorical Peaks in the Interpretation of the Quran, Tabrsi: 1/221 - 222.

22. (n.d.). Surat The Elephant / (1).

23. (n.d.). Surat Al-Fajr/(6).

24. (n.d.). The Language of the Holy Quran: A Linguistic Study of Derivatives in the First Quarter, Dr / Belgacem Balaraj: 125.

25. (n.d.). Al-Kafiah, Ibunulhajeb: 139.

26. (n.d.). Facilitation of Benefits and Supplementation of Ends/ Tasheel Al-Fawaeed wa Takmeel Al-Maqsid, Ibn Malik: 136.

27. (n.d.). Speech Strategies, Abdul Hadi Al Shihri: 488.

28. (n.d.). Surat Yusuf / 81 - 83.

29. (n.d.). Rhetorical Peaks in the Interpretation of the Quran, Tabrsi: 5/393.

30. Mafteeh, Al-Ghaib (n.d.). The Keys to the Unseen, Al - Razi:9/92.

31. (n.d.). Surat Yunus/ 20.

32. Mafteeh, Al-Ghaib (n.d.). The Keys to the Unseen, Al-Razi: 210.

33. (n.d.). Writing and Enlightenment, Ibn Ashour: $6 / 455$.

34. (n.d.). Meanings of Grammar, d. Fadel Al Samarrai: 3/153.

35. (n.d.). The Language of the Holy Quran: A Linguistic Study of Derivatives in The First Quarter, Dr / Belgacem Balaraj: 115.

36. (n.d.). Al-Kafiah, Ibunulhajeb: 141.

37. (n.d.). Al-Qalam (46).

38. (n.d.). See: See: Rhetorical Peaks in the Interpretation of the Quran, Tabrsi: 10 / 86-87, and Writing and Enlightenment, Ibn Ashour: $15 / 268$.

39. (n.d.). Speech Strategies, Abdul Hadi Al - Shihri: $489-490$.

40. (n.d.). Rawdhah Al-Ndhir wa Janat Al-mandhir, Ibn Qudaamah: 1/70 - 85.

41. (n.d.). Speech Strategies, Abdulhadi Al - Shihri: 490.

42. (n.d.). Al-Hashr (22/24).

43. (n.d.). See: Al-Mizan/ The Scale, Attabatabai: $19 / 118$.

44. (n.d.). Al-Kashaf/ The Seeker, Azzamakhshari: $7 / 35$.

45. (n.d.). Al-Mizan / The Scale, Attabatabai: 19/12 